\title{
TELAAH STRUKTURAL HERMENEUTIK KISAH NABI IBRAHIM DALAM ALQURAN
}

\author{
Zunly Nadia \\ Sekolah Tinggi Agama Islam Sunan Pandanaran Yogyakarta \\ zunlynadia5@gmail.com
}

\begin{abstract}
Abstrack: This paper attempts to analyze the Qur'anic story of Ibrahim in the light of hermeneutical structuralism. It aims at unrevealing the meaning through its relational features of the language structure in each verse. Besides, the hermeneutical approach complements to our understanding on the text in a non-structural symbolic interpretation. By these two approaches, this paper finds a paralleled analogy between the moon, stars and sun with the statue and Namrud. The relationship between these things was evident from the point that the three were considered to be gods but no one could prove their qualities possessed by God. Another parallel was apparent from the logic of the birds, fire and goats. As Ibrahim has experienced several extraordinary events in his life, these events can be found paradigmatic relations that all of them are in the frame of sacrifice, preaching, and efforts to call people on the faith in God.
\end{abstract}

Keywords: The Qur'an, Ibrahim Stories, Structuralism, Hermeneutics.

\begin{abstract}
Abstrak: Artikel ini berusaha untuk menganalisis kisah Nabi Ibrahim dalam Alquran dengna menggunakan pendekatan strukturalisme hermeneutik. Hal itu bertujuan untuk mengungkap makna kisah melalui hubungan-hubungan fitur yang tampak dalam struktur bahasa di setiap ayat. Di sisi lain, pendekatan hermeneutik digunakan untuk melengkapi pemahaman terhadap teks dalam melakukan interpretasi simbolik non-struktural. Dengan dua pendekatan ini, penulis menemukan adanya paralel analogis antara bulan, bintang dan matahari dengan patung dan Namrud. Hubungan antara hal-hal tersebut terlihat dari sebuah konformitas bahwa ketiganya dianggap sebagai tuhan, namun tidak bisa membuktikan sifat-sifat yang seharusnya dimiliki oleh Tuhan. Paralel lain yang tampak jelas adalah konformitas analogis antara burung, api, dan kambing. Oleh karena Ibrahim telah mengalami beberapa peristiwa luar biasa dalam hidupnya, peristiwa-peristiwa ini dapat ditemukan relasi paradigmatik bahwa ketiganya berada dalam bingkai pengorbanan, dakwah, dan upaya untuk menyeru keimanan kepada Allah.
\end{abstract}

Kata Kunci: Alquran, Kisah Ibrahim, Strukturalisme, Hermeneutika. 


\section{Pendahuluan}

Alquran, menurut Fazlur Rahman, adalah kitab yang "sepenuhnya ditujukan pada manusia." Dia menyebut salah satu fungsinya adalah sebagai petunjuk bagi manusia (QS. al-Baqarah [2]: 185), dan diyakini tetap aktual serta tidak akan pernah habis meskipun diungkap maknanya melewati batas ruang dan sejarah. Dengan demikian, Alquran senantiasa menjadi pegangan hidup bagi umat Islam hingga saat ini, karena memuat nilai yang lengkap, universal dan integral. ${ }^{2}$ Salah satu kemukjizatan Alquran ini bisa dilihat dari sisi keindahan bahasanya dan dengan pilihan kata yang tepat, sehingga tidak hanya memikat para pembaca dan pendengarnya, namun juga bisa dipastikan tidak ada orang yang bisa menandinginya. ${ }^{3}$

Alquran memberikan petunjuk kepada umatnya melalui beragam cara, salah satunya adalah dengan menggunakan bahasa narasi atau kisah yang digambarkan dari peristiwa umat terdahulu. Ada sekitar 1600 ayat memuat kisah tentang para Nabi, disamping juga ayat-ayat lain dengan beraneka ragam kisah seperti kisah orang bijak,

1 Fazlur Rahman, Tema-tema Pokok Al-Qur'an, terj. Ervan Nurtawab dan Ahmad Baiquni (Bandung: Mizan Pustaka, 2017), 1.

2 Alquran menjelaskan kandungannya merupakan bagian integral dari induk al-Kitäb (umm al-kitāb) yang ada disisi Allah, transendental dan penuh hikmah. Lihat QS. alZukhruf [43]: 4. Berkaitan dengan hal ini, Arkoun menulis: "Pengertian umm al-kitäb yang transenden, penuh dengan hikmah dan dipelihara di sisi Tuhan sangat penting untuk menentukan secara akurat status Alquran yang dipahami sebagai bacaanbacaan yang diartikulasikan dalam bahasa Arab untuk menjelaskan secara gamblang kepada umat manusia tentang kebenaran-kebenaran dan perintah-perintah yang dipilih oleh Tuhan untuk mengingatkan orang-orang yang berdosa sebagaimana Dia lakukan terhadap Nabi-nabi sebelum Nabi Muhammad." Lihat Mohammad Arkoun, Rethinking Islam, terj. Yudian W. Asmin dan Lathiful Khuluq (Yogyakarta: LPMI dan Pustaka Pelajar, 1996), 48.

3 Sebagaimana yang telah dikemukakan oleh M. Quraish Shihab, bahwa kemukjizatan Alquran dari sisi bahasa diantaranya adalah: (1) Dari nada dan langgamnya. Hal ini disebabkan oleh huruf dan kata-kata yang dipilih melahirkan keserasian bunyi dan kemudian kumpulan kata itu melahirkan pula keserasian irama dalam rangkaian ayat-ayatnya. (2) Gaya bahasanya yang singkat dan padat. Tidak mudah menyusun kalimat singkat, tetapi sarat makna. Hal inilah yang terdapat di dalam Alquran, di mana kata dan kalimat-kalimatnya yang singkat dapat menampung sekian banyak makna. (3) Memuaskan para pemikir dan orang kebanyakan. (4) Memuaskan akal dan jiwa. (5) Keindahan dan ketepatan maknanya. Lihat M. Quraish Shihab, Mukjizat al-Qur'an Ditinjau dari Aspek Kebahasaan, Isyarat Ilmiah, dan Pemberitaan Gaib (Bandung: Mizan, 2007), 115-158. 
historiografi, serta orang yang tersohor. ${ }^{4}$ Bahkan ada surah yang dikhususkan untuk kisah semata, seperti QS. Yūsuf, QS. al-Anbiyā', QS. al-Qașaș, dan QS. Nūḥ. Surah tersebut hanya mencakup Nabi saja, dan tidak mengikutsertakan ayat-ayat yang berisi kisah tokoh umum. Hal ini mengindikasikan betapa besar perhatian Alquran terhadap kisah-kisah. Dari segi proporsi, kisah juga menempati bagian terbanyak dalam keseluruhan isi Alquran, yaitu terdapat dalam 35 surah dan 1.600 ayat. Meski kisah-kisah ini banyak mendominasi isi Alquran, tetapi ayat-ayat tersebut kurang mendapat perhatian dari para peneliti dan pengkaji Alquran dibandingkan perhatian mereka terhadap ayat-ayat hukum, teologi dan lain-lain. ${ }^{5}$

Bertolak dari paparan di atas penulis hendak mengkaji salah satu kisah dalam Alquran, yaitu kisah Nabi Ibrahim yang terdapat dalam surah al-An'ām ayat 74-83. Dalam hal ini, penulis akan menggunakan analisa strukturalisme Levi-Strauss dan hermeneutika. Penggunaan analisa strukturalisme ini dilakukan dalam rangka mengungkapkan makna dari relasi-relasi bahasa yang terdapat di dalam kisah yang selama ini masih jarang dilakukan oleh para pengkaji Alquran. Sementara itu penggunaan hermeneutika di sini adalah untuk melengkapi analisa struktural dengan menafsirkan simbol nonstruktural. Dengan analisa strukturalisme-hermeneutik ini, setidaknya menurut penulis akan memberikan perspektif yang berbeda dari analisa yang selama ini biasa dilakukan oleh para pengkaji dan pemerhati studi Alquran.

\section{Kisah Nabi Ibrahim dalam Alquran}

Ibrahim adalah nabi yang dikenal sebagai bapak dari tiga agama samawi: Islam, Yahudi dan Nasrani. Tidak mengherankan jika kisah Nabi Ibrahim juga diceritakan secara rinci dan panjang lebar di dalam Bibel. Ibrahim memiliki posisi istimewa dalam barisan para nabi. Para ahli menyebut beberapa alasan mengapa dia menjadi pilihan dan agamanya menjadi model, di antaranya adalah: pertama, dia telah lolos dari berbagai ujian yang cukup berat, baik dari cobaan dalam keluarga maupun masyarakat, sehingga dia termasuk dalam deretan ulu al'ažm. Kedua, Ibrahim memperoleh pengertian tentang Tuhannya mula-mula melalui penalaran kritis dengan argumen-argumen yang logis. Ketiga,

\footnotetext{
4 A. Hanafi, Segi-segi Kesusastraan Pada Kisah-kisah al-Qur'an (Jakarta: Pustaka alHusna, 1983), 22.

5 Shihab, Mukjizzat Alquran, 158.
} 
Nabi Ibrahim telah memperjuangkan dan menyebarkan kepercayaannya dalam setiap kesempatan. Keempat, Ibrahim banyak menurunkan keturunan yang menjadi nabi, sehingga semua agama samawi bermuara kepadanya. ${ }^{6}$

Nama Ibrahim juga diabadikan dalam Alquran dan menjadi nama salah satu surah dalam Alquran, yaitu surah ke-14. Ibrahim juga satusatunya nabi selain Muhammad yang namanya disebut dalam salat dan sering diucapkan dalam doa tiga agama: Yahudi, Kristen dan Islam. Di dalam Alquran, kisah Nabi Ibrahim ditampilkan sebanyak 186 ayat dalam 25 Surah. Hampir setiap surah mempunyai versi masingmasing. Namun demikian, kisah Nabi Ibrahim banyak dimuat dalam 13 surah di dalam Alquran, yakni QS. al-Baqarah, QS. Āli 'Imrān, QS. al-An‘ām, QS. Hūd, QS. Ibrāhīm, QS. al-Hịr, QS. Maryam, QS. alAnbiyā', QS. al-Shu'arā̄', QS. al-'Ankabūt, QS. al-Ṣāffāt, QS. Șād, dan QS. al-Dhāriyāt.

Nama Ibrahim sendiri menurut al-Jawāliqī bukanlah berasal dari bahasa Arab, melainkan dari bahasa Suryani yang maknanya adalah "bapak yang pengasih". Ada yang mengatakan bahwa nama Ibrahim ini diambil dari akar kata Barhamah yang maknanya adalah 'tajam penglihatan'. Sedangkan menurut riwayat al-Kirmānī, Ibrahim adalah anak dari Azar yang namanya adalah Țarah b. Nahūr b. Sharūh b. Raghu b. Fāliḥ b. 'Abar b. Șaliḥ b. Arfakhṣād b. Shām b. Nūḥ. ${ }^{7}$ Nama Azar yang dikenal dengan bapak Ibrahim ini menurut riwayat dari Ibn Hātim bukanlah nama sebenarnya. Nama sebenarnya adalah Ṭarah dan Azar adalah nama gelar untuknya yang bermakna berhala. ${ }^{8}$ Demikian juga menurut Ṭabātabā̄̄, yang menyatakan bahwa Azar

${ }^{6}$ Dawan Raharjo, Ensiklopedi Alquran: Tafsir Sosial Berdasarkan Konsep-konsep Kunci (Paramadina: Jakarta, 2002), 88.

7 Jalāl al-Dīn al-Suyuṭī, Al-Itqān fì 'Ulüm al-Qư'àn, vol. 4 (Kairo: Hai'at al-Mișriyyah al-'Āmmāh li al-Kitāb, 1974), 84. Dalam tafsir Ibn Kathīr juga disebutkan beberapa pendapat para ulama tentang Azar, apakah dia ayah Ibrahim atau bukan. Ada yang menyatakan bahwa Azar adalah ayah Ibrahim, tetapi ada juga yang menyatakan sebaliknya. Diantaranya adalah menurut Mujāhid dan al-Saddī yang mengatakan bahwa Azar adalah berhala. Berdasarkan pendapat ini dia dikenal dengan nama Azar karena dialah pelayan dan yang mengurus berhala. Sedangkan menurut ulama lain yang dikutip oleh Ibn Jarīr menyebut bahwa Azar menurut bahasa mereka berarti kata cacian, maknanya ialah menyimpang (sesat). Namun menurut Ibn Jarīr pendapat ini tidaklah kuat. Lihat Abū al-Fidā' Ismā'îl b. Kathīr, Tafsìr al-Qur'ān al'Ažim, vol. 3 (Kairo: Dār Ṭayyibah, 1999), 288.

8 Ibid. 
bukanlah nama ayah Ibrahim yang hakiki, tetapi kemungkinan adalah pamannya atau kakek dari pihak ibu.

Ibrahim lahir sekitar 2000 SM., di daerah yang bernama Ur, sebuah kota kecil yang terletak di Kaldea, Babilonia. Ibrahim lahir dan tumbuh dewasa sampai menjadi nabi di tengah masyarakat yang politeis; realitas masyarakat penyembah berhala. Di samping masyarakat penyembah berhala, masyarakat pada masa Ibrahim juga menyembah bintang-bintang. Mereka menganggap bahwa yang asli disembah adalah spiritualitas bintang-bintang tersebut. Sebagai sarana penyembahan, maka dibangunlah kuil-kuil yang kemudian diisi dengan patung-patung. Kuil-kuil tersebut berdiri di pusat kota sebagai lambang sentral peranan kepercayaan dalam kehidupan mereka. ${ }^{9}$

Kisah Nabi Ibrahim di dalam Alquran sering ditampilkan dalam konteks dialog, sehingga lafal-lafal seperti qāla, qālū, qulnā, yaqūl dan yaqülün kerap dipergunakan. Dialog di sini dapat menggambarkan kepribadian pelakunya. Hal tersebut dengan memperhatikan cara pengungkapan bisikan jiwanya, pendapatnya, dan sikapnya tatkala terjadi perselisihan di antara mereka. Jika dilihat dari tema-temanya, maka dialog dalam kisah Nabi Ibrahim dapat dikelompokkan ke dalam enam bentuk: ${ }^{10}$ (1) Dialog tentang tauhid, seperti dalam QS. alAnbiyà' [21]: 52-68, QS. Maryam [19]: 42-47; (2) Dialog tentang fenomena alam, seperti dalam QS. al-An'ām [6]: 76-79; (3) Dialog dengan raja Namrud, seperti dalam surah al-Baqarah [2]: 258; (4) Dialog tentang menghidupkan yang mati, seperti dalam surah alBaqarah [2]: 260; (5) Dialog tentang kurban, seperti dalam surah alṢāfāt ayat 100-102; (6) Dialog tentang penghormatan kepada tamu, dalam surah al-Dhāriyāt [51]: 24-27.

\section{Analisa Strukturalisme dan Hermeneutik Terhadap Kisah Nabi Ibrahim dalam Alquran}

Sebagaimana yang telah dijelaskan di atas bahwa kisah Nabi Ibrahim tersebar di 186 ayat dalam 25 surah dalam Alquran. Hampir setiap surah memiliki karakteristik masing-masing, sehingga untuk memahami struktur kisah dari versi cerita atau episode harus dilihat

\footnotetext{
${ }^{9}$ Waryono Abdul Ghafur, Millah Ibrabim dalam Tafsir Al-Mizan fi Tafsir Alquran karya Mubammad Husein Ath-Thaba'thaba'i (Yogyakarta: Bidang Akademik UIN Sunan Kalijaga, 2008), 123-124.

10 Shihabbuddin Qalyubi, Stilistika Alquran: Makna di Balik Kisab Ibrahim (Yogyakarta: LKiS, 2008), 221-222.
} 
tidak hanya secara sintagmatis tetapi juga secara paradigmatis. Secara keseluruhan, beberapa versi atau episode cerita Nabi Ibrahim AS di dalam Alquran adalah: (1) Pendahuluan (berita tentang pengutusan Ibrahim), terdapat dalam QS. al-Baqarah, QS. Āli 'Imrān, QS. Maryam, QS. al-Anbiyā’, QS. al-Shu'arā’’, QS. al-Ṣāffāt, dan QS. Ṣād; (2) Dakwah terhadap bapaknya, yang terdapat dalam QS. al-An'ām, QS. Maryam, QS. al-Anbiyā', QS. al-Shu'arā', dan QS. al-Ṣāffāt; (3) Ibrahim melihat fenomena alam terdapat dalam surah al-An'ām dan surah al-Ṣāffāt; (4) Dialog dengan kaumnya terdapat dalam QS. alAn'ām, QS. al-Anbiyā', QS. al-Shu'arā', QS. al-'Ankabūt, dan QS. alȘāffāt; (5) Ibrahim menghancurkan berhala terdapat dalam surah alAnbiyā' dan al-Ṣāffāt; (6) Ibrahim dibakar terdapat dalam surah alAnbiyā', al-'Ankabūt, dan al-Ṣāffāt; (7) Ibrahim dan Namrud terdapat surah al-Baqarah; (8) Menghidupkan burung, terdapat dalam surah alBaqarah; (9) Ibrahim bersama Ismāîn di Mekkah terdapat dalam QS. al-Baqarah, QS. Āli 'Imrān, QS. Ibrāhim dan QS. al-Ṣāffāt; (10) Kelahiran Isḥāq yang terdapat dalam QS. al-An‘ām, QS. Hūd, QS. alHiijr, QS. Maryam, QS. al-Anbiyā’, QS. al-'Ankabūt, QS. al-Ṣāffāt, dan QS. al-Dhāriyāt; (11) Pribadi Ibrahim terdapat dalam surah al-Nahl dan Ṣād, al-Mumtaḥanah; (12) Istigfar untuk bapaknya terdapat surah al-Tawbah.

Di bawah ini adalah episode kisah Ibrahim dilihat secara paradigmatis menyebar di dalam 13 surah yang memuat paling banyak kisah Ibrahim:

\begin{tabular}{|c|c|c|c|c|c|c|c|c|c|c|c|c|c|}
\hline Episode & $\mathrm{A}$ & $\mathrm{B}$ & $\mathrm{C}$ & $\mathrm{D}$ & $\mathrm{E}$ & $\mathrm{F}$ & $\mathrm{G}$ & $\mathrm{H}$ & $\mathrm{I}$ & $\mathrm{J}$ & $\mathrm{K}$ & $\mathrm{L}$ & $\mathrm{M}$ \\
\hline 1 & $*$ & $*$ & & & & & $*$ & $*$ & $*$ & & $*$ & $*$ & \\
\hline 2 & & & $*$ & & & & $*$ & $*$ & $*$ & & $*$ & & \\
\hline 3 & & & $*$ & & & & & & & & & & \\
\hline 4 & & & $*$ & & & & & $*$ & $*$ & $*$ & $*$ & & \\
\hline 5 & & & & & & & & $*$ & & & $*$ & & \\
\hline 6 & & & & & & & & $*$ & & $*$ & $*$ & & \\
\hline 7 & $*$ & & & & & & & & & & & & \\
\hline 8 & $*$ & & & & & & & & & & & & \\
\hline 9 & $*$ & $*$ & & & $*$ & & & & & & $*$ & & \\
\hline 10 & & & $*$ & $*$ & & $*$ & $*$ & $*$ & & $*$ & $*$ & & $*$ \\
\hline
\end{tabular}

Ket:
A. Surah al-Baqarah
F. Surah al-Hijr
K. Surah al-Ṣāfā̄t
B. Surah Āli 'Imrān
G. Surah Maryam
L. Surah Ṣād
C. Surah al-An'ām
H. Surah al-Anbiyā'
M. Surah al-Dhāriyāt 

D. Surah Hūd
I. Surah al-Shu'arā'
E. Surah Ibrāhīm
J. Surah al-'Ankabūt

\section{Ibrahim, Azar, dan konflik teologis}

Potongan dialog antara nabi Ibrahim dan bapaknya dalam surah al-An'ām ayat 74 disebutkan:

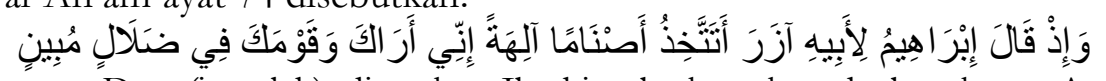

Dan (ingatlah) di waktu Ibrahim berkata kepada bapaknya, Azar, Pantaskah kamu menjadikan berhala-berhala sebagai tuhan-tuhan? Sesungguhnya aku melihat kamu dan kaummu dalam kesesatan yang nyata. ${ }^{11}$

Ayat ini menunjukkan adanya pengalaman nabi Ibrahim yang berdakwah dan menasehati bapaknya yang menyembah berhala dan melarangnya serta memperingatkannya agar meninggalkan berhalaberhala itu, tetapi ayahnya tidak mau menghentikan perbuatannya. Kesesatan yang nyata disini dimaksudkan adalah jalan yang sesat, tidak mengetahui petunjuk jalan yang ditempuh. Dengan kata lain, berada dalam keadaan bodoh bagi penilaian orang yang mempunyai akal sehat. ${ }^{12}$

Dalam ayat 74 surah al-An‘ām ini, sosok nabi Ibrahim dan ayahnya Azar bisa dilihat dalam rangkaian sebagai berikut:

\begin{tabular}{|c|c|c|}
\hline Ibrahim & & $\begin{array}{l}\text { - Anak } \\
\text { - Tidak percaya kepada berhala } \\
\text { - di jalan Allah }\end{array}$ \\
\hline Azar & Satu Keluarga & $\begin{array}{l}\text { - Bapak } \\
\text { - Menyembah berhala } \\
\text { - Di jalan yang sesat } \\
\text { - Paman }\end{array}$ \\
\hline
\end{tabular}

Dialog Nabi Ibrahim dan ayahnya, Azar, dalam ayat ini berelasi secara paradigmatik dalam surah-surah yang lain, yakni dalam QS. Maryam [19]: 41-49, QS al-Anbiyā'’ [21]: 51-72, dan QS. al-Shu'arā' [26]: 69-87, QS. al-Ṣāffāt [37]: 83-98.

Dari berbagai ayat diatas, Sosok Ibrahim dan Azar juga bisa digambarkan sebagai berikut:

\footnotetext{
11 Departemen Agama RI, Al-Hikmah: Al-Quran dan Terjemahnya (Bandung: Diponegoro, 2008), 137.

12 Kathīr, Tafsìr al-Qur'än, vol. 3, 288.
} 


\begin{tabular}{|l|l|l|l|}
\hline Ibrahim & $\begin{array}{l}\text { Percaya kepada Zat } \\
\text { yang Maha Tinggi }\end{array}$ & $\begin{array}{l}\text { Menggunakan } \\
\text { kekuatan akal }\end{array}$ & $\begin{array}{l}\text { Mendapat } \\
\text { petunjuk }\end{array}$ \\
\hline $\begin{array}{l}\text { Ayah dan } \\
\text { kaum }\end{array}$ & $\begin{array}{l}\text { Percaya kepada Zat } \\
\text { yang Maha Tinggi }\end{array}$ & $\begin{array}{l}\text { Tidak } \\
\text { menggunakan } \\
\text { kekuatan akal }\end{array}$ & $\begin{array}{l}\text { Tidak } \\
\text { mendapat } \\
\text { petunjuk }\end{array}$ \\
\hline
\end{tabular}

Selain sosok Ibrahim dan ayahnya, di dalam dialog tersebut terlihat alasan mengapa keduanya menyembah Tuhan yang berbeda. Dalam hal ini dapat dilihat di bawah ini:

\begin{tabular}{|l|l|l|}
\hline Ibrahim & Menyembah & - Karena Allah yang memberi petunjuk \\
& Allah & - Memberi Makan dan Minum \\
& & - Menyembuhkan di saat sakit \\
& & - Mematikan dan menghidupkan kembali \\
& & - Mengampuni kesalahan \\
& & - Memberi rizki \\
\hline Azar dan & Menyembah & - Karena mengikuti nenek moyang \\
kaumnya & berhala & - Mengikuti bapak-bapak mereka \\
\hline
\end{tabular}

Sementara itu berhala yang menjadi objek penting dalam dialog antara Ibrahim dan Azar dapat dideskripsikan sebagai berikut:

\begin{tabular}{|c|c|c|c|}
\hline Ibrahim & $\begin{array}{l}\text { Terhadap } \\
\text { berhala/patung }\end{array}$ & $\begin{array}{l}\text { Menganggapnya } \\
\text { sebagai setan }\end{array}$ & $\begin{array}{l}\text { - Tidak memberi } \\
\text { manfaat } \\
\text { - Tidak bisa mendengar } \\
\text { - Tidak bisa menolong } \\
\text { - Musuh }\end{array}$ \\
\hline $\begin{array}{l}\text { Azar } \\
\text { dan } \\
\text { kaumnya }\end{array}$ & $\begin{array}{l}\text { Terhadap } \\
\text { berhala/patung }\end{array}$ & $\begin{array}{l}\text { Menganggapnya } \\
\text { sebagai tuhan }\end{array}$ & - Sesembahan \\
\hline
\end{tabular}

Dialog yang terjadi antara Ibrahim dan Azar serta kaumnya diatas memperlihatkan bagaimana cara-cara dakwah yang dilakukan oleh Ibrahim dengan cara santun dan dialogis. Mengedepankan dialog dalam berdakwah adalah hal yang sangat penting dari berdakwah dengan cara kekerasan atau ancaman. Rasa hormat kepada sang ayah tetap dilakukan, meskipun ayahnya adalah seorang yang keras kepala. Ibrahim terus mendoakan ayahnya agar selalu diberikan petunjuk di jalan yang benar dan mengikutinya untuk menyembah Tuhan Allah, serta meninggalkan berhala yang selama ini menjadi sesembahannya. 
Apa yang dilakukan oleh Azar dan kaumnya dianggap sebuah kesia-siaan oleh Ibrahim. Hal ini karena: pertama, dalam beribadah akan tampak kerendahan dan kehinaan dari seorang penyembah kepada yang disembah. Seorang penyembah harus mengetahui hakekat yang disembah. Berhala adalah benda mati yang tidak memiliki jiwa, tidak dapat mendengar dan melihat, sehingga menyembahnya adalah sesuatu yang sia-sia. Kedua, ibadah, doa dan penyampaian kebutuhan kepada sesuatu tidak akan tercapai kecuali pelakunya sadar bahwa sesuatu itu mampu memberi manfaat atau dapat menolak bahaya. Berhala tidak memiliki kemampuan apa-apa yang dapat mencukupkan penyembahnya, baik memberi manfaat atau menghindarkan dari bahaya. Karena itu, menyembahnya adalah siasia. $^{13}$

Perlu digarisbawahi juga bahwa kisah Nabi Ibrahim selain sebagai tuntutan untuk tidak berperilaku syirik, juga terkait dengan apa yang dialami oleh Muhammad sebagai penerima wahyu. Hal ini senada dengan apa yang dinyatakan oleh al-Jābirī bahwa sebuah ayat kisah yang diturunkan kepada Muhammad itu tentu sangat erat hubungannya dengan kondisi yang dialami oleh Nabi Muhammad saat melakukan dakwah, sehingga penurunan ayat-ayat kisah ini juga tidak terlepas dari tujuan penetapan kebenaran tentang wahyu dan risalah yang dibawa oleh Nabi. ${ }^{14}$ Sehingga pembacaan terhadap ayat kisah ini secara tidak langsung juga dapat mengurai perjalanan dakwah Muhammad.

\section{Ibrahim dan Kegelisahan Teologis}

Setelah mendeskripsikan ayat tentang dialog antara Ibrahim dan Azar dalam surah al-An‘̄am, ayat berikutnya bercerita tentang

13 Ghafur, Millah Ibrahim, 135.

14 Diturunkanlah ayat-ayat tentang pengalaman nabi Ibrahim ketika menghadapi persoalan yang sama (meluruskan kepercayaan paham politeisme) agar bisa diteladani oleh Muhammad. Ayat tentang kisah nabi Ibrahim ini juga bertujuan untuk menuntun nabi Muhammad dan umat Islam yang pada saat itu masih dalam kondisi yang lemah, bagaimana bersikap terhadap orang-orang musyrik yang mempersekutukan Allah. Kisah Ibrahim ini juga meringankan beban jiwa dan tekanan jiwa nabi Muhammad dan orang-orang yang beriman. Karena kadangkala beban tersebut dirasakan sangat berat sehingga membuat hati nabi Muhammad terasa sempit. Sehingga dengan hadirnya kisah, setidaknya dapat mengurangi beban yang dirasakan berat oleh nabi Muhammad. M. 'Abīd al-Jābirī, Madkhal ilā al-Qur'ān al-Karim: al-Juz al-Awwal fi al-Ta'rîf bi al-Qur'ān (Beirut: Markaz Dirāsat al-Wiḥdah al'Arabīyah, 2006), 411-422. 
kegelisahan teologis yang dialami oleh nabi Ibrahim, dimana disebutkan pada surah al-An'ām [6]: 75-80,

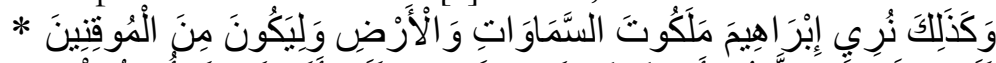

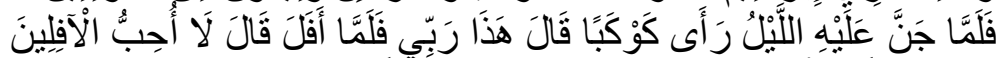

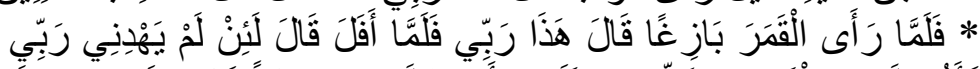

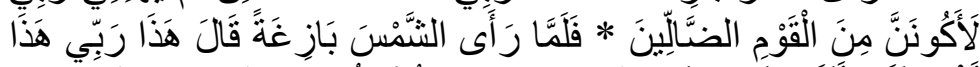

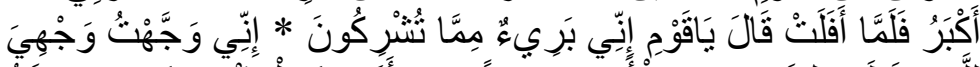

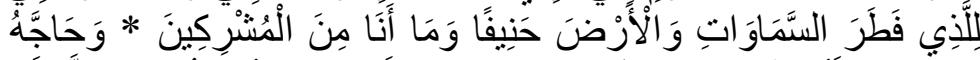

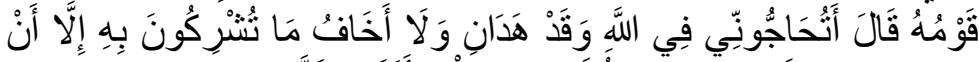

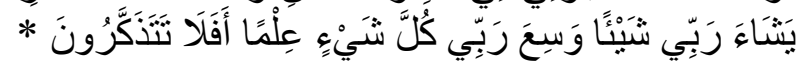

Dan Demikianlah Kami perlihatkan kepada Ibrahim tanda-tanda keagungan (kami yang terdapat) di langit dan bumi dan (kami memperlihatkannya) agar Dia Termasuk orang yang yakin (75). Ketika malam telah gelap, Dia melihat sebuah bintang (lalu) Dia berkata: 'Inilah Tuhanku', tetapi tatkala bintang itu tenggelam Dia berkata: 'Saya tidak suka kepada yang tenggelam (76). Kemudian tatkala Dia melihat bulan terbit Dia berkata: 'Inilah Tuhanku'. tetapi setelah bulan itu terbenam, Dia berkata: 'Sesungguhnya jika Tuhanku tidak memberi petunjuk kepadaKu, pastilah aku Termasuk orang yang sesat.' (77). Kemudian tatkala dia melihat matahari terbit, Dia berkata: 'Inilah Tuhanku, ini yang lebih besar'. Maka tatkala matahari itu terbenam, Dia berkata: 'Hai kaumku, Sesungguhnya aku berlepas diri dari apa yang kamu persekutukan'. (78). Sesungguhnya aku menghadapkan diriku kepada Rabb yang menciptakan langit dan bumi, dengan cenderung kepada agama yang benar, dan aku bukanlah Termasuk orang-orang yang mempersekutukan tuhan. (79). Dan Dia dibantah oleh kaumnya. Dia berkata: 'Apakah kamu hendak membantah tentang Allah, Padahal Sesungguhnya Allah telah memberi petunjuk kepadaku'. dan aku tidak takut kepada (malapetaka dari) sembahan-sembahan yang kamu persekutukan dengan Allah, kecuali di kala Tuhanku menghendaki sesuatu (dari malapetaka) itu. pengetahuan Tuhanku meliputi segala sesuatu. Maka Apakah kamu tidak dapat mengambil pelajaran? (80)..$^{15}$

Kegelisahan tologis Ibrahim, dapat digambarkan sebagai berikut:

\begin{tabular}{|c|c|c|c|c|}
\hline \multirow{2}{*}{ Ibrahim } & \multirow{2}{*}{$\begin{array}{l}\text { - Bintang } \\
\text { - Bulan } \\
\text { - Matahari }\end{array}$} & Terbit & Sesembahan & \multirow{2}{*}{$\begin{array}{c}\text { Bukan Tuhan } \\
\text { yang } \\
\text { sesungguhnya }\end{array}$} \\
\hline & & $\begin{array}{c}\text { Tenggelam/ } \\
\text { terbenam }\end{array}$ & $\begin{array}{c}\text { Bukan } \\
\text { sesembahan }\end{array}$ & \\
\hline
\end{tabular}

${ }^{15}$ Departemen Agama, Al-Hikmah, 137. 
Kegelisahan teologis Ibrahim sebagaimana yang digambarkan diatas juga menjadi titik tolak perbedaan teologis Ibrahim dengan Azar dan kaumnya. Ayat diatas merupakan argumen yang meyakinkan bahwa Ibrahim tidak suka terhadap sesuatu yang tenggelam. Hal ini karena secara aksiomatis, manusia beribadah kepada Tuhan, karena merupakan fitrah manusia bahwa dia tidak tergantung kepada sesuatu yang tidak permanen. Ibrahim juga berargumen bahwa benda langit, seperti bintang, bulan dan matahari yang disembah oleh kaumnya, tidak bisa memelihara dan mengatur alam, baik alam bumi maupun alam manusia.

Dari relasi paradigmatik ayat-ayat diatas, konflik teologis antara Ibrahim dan Azar serta petualangan teologis Ibrahim ini kemudian dapat dilihat urutannya secara diakronik, yakni mulai dari daya kritis Ibrahim kecil terhadap berhala-berhala yang disembah oleh ayah dan kaumnya. Kemudian dengan bertambahnya, usia Ibrahim mulai berani mengemukakan letak kesesatan ayahnya. Lalu adanya penegasan bahwa ayah dan kaumnya berada dalam kesesatan yang nyata. Hingga kemudian fase dimana Ibrahim terlibat konflik ideologis.

Diawali dengan pertanyaan Ibrahim tentang apakah berhala itu pantas dijadikan sesembahan (Tuhan), di mana pertanyaan itu merupakan kegelisahan Ibrahim dan kemudian terjawab melalui tanda-tanda alam (bintang, bulan dan matahari) yang diperlihatkan kepadanya dan menimbulkan keyakinan bahwa seharusnya Tuhan yang pantas disembah bukanlah tuhan yang muncul kemudian tenggelam, melainkan Tuhan pencipta langit dan bumi, yang tidak ada satupun dapat mempersekutukan-Nya.

Semakin bertambah usia, pengetahuan Ibrahim semakin bertambah. Di sini Ibrahim semakin berani mengungkapkan alasan kesesatan ayah dan kaumnya. Pertanyaan yang muncul dari Ibrahim semakin kritis. Apakah berhala itu memberi manfaat atau mudarat? Lalu Ibrahim mempertegas dengan pernyataan bahwa apa yang disembah adalah "musuhku kecuali Tuhan semesta, yang menciptakan aku, yang menunjuki aku, yang memberi makan dan minum, yang menyembuhkan, yang mematikan dan menghidupkan kembali dan yang mengampuni kesalahanku". Perbedaan dan konflik teologis antara ayah dan anak itu semakin memuncak dengan kemarahan ayahnya yang mengancam hendak merajam Ibrahim jika terus berdakwah dengan keyakinan seperti itu. Kemarahan ayah Ibrahim 
tersebut dibalas dengan doa Ibrahim, salah satunya adalah dengan memohon pengampunan untuk ayahnya karena dia termasuk golongan yang sesat.

\section{Ibrahim dan Penghancuran Patung}

Kisah Nabi Ibrahim tentang penghancuran patung bermula dari dialog Ibrahim dengan patung, yang dilakukan pada saat kaumnya meninggalkan tempat. Hal ini bisa digambarkan sebagai berikut:

\begin{tabular}{|l|l|l|ll|}
\hline Ibrahim & $\begin{array}{l}\text { Manusia ciptaan } \\
\text { Allah }\end{array}$ & $\begin{array}{l}\text { Bisa bicara / } \\
\text { bertanya }\end{array}$ & $\begin{array}{l}\text { Bisa menghancurkan } \\
\text { patung }\end{array}$ \\
\hline Patung & Buatan manusia & $\begin{array}{l}\text { Tidak bisa bicara } \\
\text { Tidak bisa } \\
\text { menjawab bisa }\end{array}$ & $\begin{array}{l}\text { Tidak } \\
\text { menghancurkan } \\
\text { patung }\end{array}$ \\
\hline
\end{tabular}

Patung yang disembah oleh kaum Ibrahim itu cukup banyak, tetapi yang terbesar mereka namai Ball. Patung ini terbuat dari emas yang melambangkan matahari. Ibrahim menyebutnya sebagai patungpatung, bukan menamainya tuhan-tuhan atau menyebut namanya secara langsung. ${ }^{16}$

Pada fase ini, Nabi Ibrahim dengan tegas menyatakan kesesatan yang nyata dilakukan oleh ayah dan kaumnya. Meski tetap diawali dengan membangun dialog, Nabi Ibrahim juga menggunakan cara lain, yakni dengan menghancurkan berhala-berhala untuk bisa memberikan pelajaran nyata bahwa berhala tidaklah pantas untuk disembah karena tidak bisa berbuat apa-apa. Sebelum menghancurkan berhala-berhala tersebut, Nabi Ibrahim juga mengawalinya dengan "dialog", meskipun dia sadar patung tersebut tidak akan bisa diajak berbicara. Tidak semua patung dirusak oleh Ibrahim. Dia menyisakan satu patung yang paling besar, dengan tujuan jika kaumnya bertanya kepadanya dapat dengan mudah dia menjawab argumen bahwa menyebut berhala sebagai Tuhan merupakan hal yang tidak benar karena berhala tidak bisa berbuat apa-apa. Sehingga, itu menjadi bukti kelemahan berhala sekaligus ketidakwajaran untuk disembah.

\section{Pembakaran Ibrahim}

Perbuatan Ibrahim yang menghancurkan patung-patung sesembahan ayah dan kaumnya menuai reaksi. Hal ini membuat Ibrahim ditangkap untuk kemudian dibakar, sebagai hukuman atas

${ }_{16}$ M. Quraish Shihab, Tafsir al-Mishbah: Kesan, Pesan dan Keserasian Alquran, vol. 3 (Jakarta: Lentera Hati, 2002), 75. 
pengrusakan berhala yang telah dilakukannya. Menurut Sulaymān alTaharāwah, sebagaimana yang dikutip oleh Waryono, pembakaran bukan sekedar cara untuk membunuhnya sebagai hukuman. Namun lebih dari itu, hukum bakar tersebut diduga berkaitan dengan upacara ritual yang telah menjadi tradisi mereka. Ada unsur kesengajaan untuk menjadikan Ibrahim sebagai tumbal bagi tuhan-tuhan mereka. Pembakaran juga dimaksudkan sebagai upaya pembersihan jiwa Ibrahim akibat tindakannya terhadap tuhan-tuhan mereka. ${ }^{17}$

Reaksi pembakaran Ibrahim bermula pada dialog dengan kaumnya, yang menjadikan kaum Nabi Ibrahim menjadi terpojok dan sangat marah. Sehingga mereka kemudian mendiskusikan sikap yang harus mereka ambil terhadap Nabi Ibrahim. Akhirnya, mereka sepakat untuk menghabisi Nabi Ibrahim dengan cara membakarnya. Mereka mengumpulkan bahan bakar secukupnya lalu menyalakan api sebesar mungkin. Setelah itu mereka melempar Nabi Ibrahim dengan manjaniq, yaitu semacam ketapel besar, ke tengah kobaran api. Mereka melakukan hal tersebut untuk menghindari sengatan api yang terasa panas dari jarak jauh. Namun, Allah memperlihatkan mukjizat-Nya dengan menjadikan api terasa dingin bagi Ibrahim, sehingga dia terselamatkan. ${ }^{18}$ Episode ini bisa digambarkan sebagai berikut:

\begin{tabular}{|l|l|l|l|l|l|}
\hline Ibrahim & $\begin{array}{l}\text { Mengajak } \\
\text { menyembah } \\
\text { Allah }\end{array}$ & $\begin{array}{l}\text { Dibakar } \\
\text { Dibunuh } \\
\text { pertolongan } \\
\text { Allah }\end{array}$ & $\begin{array}{l}\text { Merasakan } \\
\text { api yang } \\
\text { dingin }\end{array}$ & $\begin{array}{l}\text { Tidak } \\
\text { terbakar } \\
\text { dan } \\
\text { selamat } \\
\text { karena } \\
\text { pertolonga } \\
\text { n Allah }\end{array}$ \\
\hline Kaum & $\begin{array}{l}\text { Tidak mau } \\
\text { menyembah } \\
\text { Allah }\end{array}$ & $\begin{array}{l}\text { Membakar } \\
\text { Membunuh }\end{array}$ & $\begin{array}{l}\text { Tidak bisa } \\
\text { berbuat } \\
\text { apa-apa }\end{array}$ & $\begin{array}{l}\text { Mengira } \\
\text { api panas }\end{array}$ & $\begin{array}{l}\text { Mengira } \\
\text { Ibrahim } \\
\text { mati }\end{array}$ \\
\hline
\end{tabular}

\section{Ibrahim dan Raja Namrud}

Episode tentang dialog Ibrahim dan Raja Namrud ini terdapat dalam QS. al-Baqarah [2]: 258-260. Namrud adalah raja dari kerajaan Babylon yang berkuasa dengan zalim. Dia bahkan mengaku Tuhan. Nabi Ibrahim berdialog dengan raja Namrud dalam rangka berdakwah untuk mengajak menyembah kepada Allah. Dialog Ibrahim dengan Namrud bisa digambarkan sebagai berikut:

\begin{tabular}{|l|l|l|l|l|l|l|}
\hline Ibrahim & Manusia & Nabi & Merasa & Menyem- & Mendapat & Seorang \\
\hline
\end{tabular}

17 Ghafur, Millah Ibrabim, 136.

18 Shihab, Tafsir al-Mishbah, vol. 3, 83-84. 


\begin{tabular}{|l|l|l|l|l|l|l|}
\hline & & & $\begin{array}{l}\text { dirinya } \\
\text { hamba }\end{array}$ & bah Allah & petunjuk & $\begin{array}{l}\text { hanif dan } \\
\text { muslim }\end{array}$ \\
\hline Namrud & Manusia & Raja & $\begin{array}{l}\text { Merasa } \\
\text { dirinya } \\
\text { tuhan }\end{array}$ & $\begin{array}{l}\text { Tidak } \\
\text { mau } \\
\text { menyem- } \\
\text { bah Allah }\end{array}$ & $\begin{array}{l}\text { Tidak } \\
\text { mendapat } \\
\text { petunjuk }\end{array}$ & $\begin{array}{l}\text { Seorang } \\
\text { kafir dan } \\
\text { zalim }\end{array}$ \\
\hline
\end{tabular}

Dalam dialognya, Namrud menuntut untuk membuktikan kebenaran eksistensi Tuhan yang dipercaya oleh Ibrahim. Bagaimana Tuhan bisa mematikan dan kemudian menghidupkan kembali. Lalu Nabi Ibrahim berdoa kepada Tuhan dan meminta-Nya untuk membuktikan kebesaran-Nya, agar bisa meyakinkan kaumnya dan memantapkan hati dan imannya sendiri. Lalu Allah menyuruh Ibrahim untuk mengambil empat ekor burung dan mencincangnya. Setelah itu, diletakkannya beberapa bagian burung yang dicincang itu di beberapa bukit. Lalu Allah menyuruh Ibrahim untuk memanggil burung yang dicincang dan setelah dipanggil, burung itu akhirnya bisa kembali seperti sedia kala. Terkait dengan hal ini dapat dilihat dari gambaran berikut:

\begin{tabular}{|l|l|l|}
\hline Tuhan Allah & $\begin{array}{l}\text { Tuhan yang } \\
\text { sesungguhnya }\end{array}$ & $\begin{array}{l}\text { Bisa membuktikan kebesaran-Nya } \\
\text { dengan menghidupkan burugnyang } \\
\text { mati dan menerbitkan matahari dari } \\
\text { Timur }\end{array}$ \\
\hline Namrud & $\begin{array}{l}\text { Merasa dirinya } \\
\text { tuhan }\end{array}$ & $\begin{array}{l}\text { Tidak bisa membuktikan } \\
\text { ketuhanannya }\end{array}$ \\
\hline
\end{tabular}

\section{Ibrahim dan Ismā'īil di Mekkah}

Terdapat kisah Ibrahim yang membangun ka'bah bersama Ismā'îl di Mekkah, yang tercantum dalam QS. al-Baqarah [2]: 124-127, dan Baitullah yang menjadi tempat beribadah kepada Allah. Baitullah merupakan warisan Ibrahim yang masih terus terpelihara hingga saat ini, yang setiap tahun menjadi tujuan ibadah haji oleh semua umat muslim. Kisah tentang dibangunnya fondasi ka'bah di dalam surah alBaqarah dan berelasi secara paradigmatik dengan QS. Āli 'Imrān, QS. Ibrāhīm dan QS. al-Ṣāffāt bisa digambarkan sebagai berikut:

\begin{tabular}{|c|c|c|c|c|c|c|c|}
\hline Ibrahim & Nabi & $\begin{array}{l}\text { Bapa } \\
\text { k }\end{array}$ & \multirow[t]{2}{*}{$\begin{array}{l}\text { Membersih } \\
\text { kan } \\
\text { baitullah } \\
\text { Membangu } \\
\mathrm{n} \text { fondasi } \\
\text { kabah }\end{array}$} & \multirow{2}{*}{$\begin{array}{l}\text { Menjadi } \\
\text { rumah } \\
\text { pertama } \\
\text { yang } \\
\text { dibangun } \\
\text { untuk } \\
\text { tempat } \\
\text { ibadah }\end{array}$} & \multirow{2}{*}{$\begin{array}{l}\text { Tempat } \\
\text { memeprole } \\
\text { h pahala } \\
\text { Tempat } \\
\text { yang aman } \\
\text { Tempat } \\
\text { yang } \\
\text { diberkahi }\end{array}$} & \multirow{2}{*}{$\begin{array}{l}\text { Tempa } \\
t \text { salat } \\
\text { untuk } \\
\text { orang } \\
\text { yang } \\
\text { tawaf, } \\
\text { iktikaf, } \\
\text { dan }\end{array}$} & \multirow{2}{*}{$\begin{array}{l}\text { Temp } \\
\text { at } \\
\text { yang } \\
\text { menja } \\
\text { di } \\
\text { petun } \\
\text { uk } \\
\text { bagi }\end{array}$} \\
\hline Ismāīil & Nabi & Anak & & & & & \\
\hline
\end{tabular}




\begin{tabular}{|l|l|l|l|l|l|l|l|}
\hline & & & & & & sujud & $\begin{array}{l}\text { manus } \\
\text { ia }\end{array}$ \\
\hline
\end{tabular}

\section{Kelahiran Ishạāq}

Dalam Alquran juga terdapat kisah Ibrahim yang mendapatkan anugerah seorang putera bernama Ishāa. Seorang putera yang telah lama didambakannya. Ishāa adalah putera kedua Ibrahim dari istri pertamanya Sarah. Kelahiran Ishāa ini merupakan kelahiran yang tidak pernah disangka, karena meski Ibrahim tidak pernah putus asa dalam berdoa kepada Allah, namun Ibrahim yang saat itu telah tua dan kondisi istrinya yang dianggap mandul secara akal sehat tidak memungkinkan untuk mendapat keturunan. Pada saat itu, Nabi Ibrahim telah berusia 100 tahun dan Sarah berusia sekitar 90 tahun. Sebagaimana diketahui, sebelum kelahiran Ishạā, Nabi Ibrahim yang sangat mendambakan keturunan pernah meminta izin kepada Sarah untuk menikahi Hajar dan akhirnya memperoleh seorang putra (Ismā̄ill). Hadirnya Ismā'īl ini membuat rumah tangga Ibrahim semakin hidup dan menyita perhatiannya. Hal ini membuat Sarah cemburu dan sering terlibat konflik dengan Hajar. Maka Sarah meminta agar Hajar dan anaknya dijauhkan dari rumah tangganya. Akhirnya dengan berat hati, dan atas perintah Allah, Ibrahim pergi bersama mereka ke selatan Kan'an (Palestina), di suatu lembah yang kering dan tandus, sehingga tidak ada tumbuhan. Lembah tersebut sekarang dikenal dengan Mekkah.

Setelah kembali kembali ke Palestina, datanglah kabar kelahiran Ishāa yang disampaikan oleh malaikat yang menyamar sebagai seorang manusia. Malaikat ini bertamu ke rumah Ibrahim, dimana kehadirannya tidak diketahui sebelumnya oleh Ibrahim dan Sarah. Ibrahim memberikan jamuan yang lezat kepada tamu tersebut tetapi tidak dimakan oleh mereka. Kemudian tamu tersebut mengaku sebagai seorang malaikat utusan Allah yang datang untuk memberikan kabar gembira, bahwa mereka akan dikaruniai seorang putera. Meski pada awalnya mereka terkejut, tetapi baik Ibrahim maupun Sarah sangat berbahagia dengan kabar tersebut. Kelahiran Isḥāq ini diceritakan di dalam beberapa surah, yakni QS. al-An‘ām, Hūd, alḤijr, Maryam, al-Anbiyā’, al-'Ankabūt, al-Ṣāffāt, dan al-Dhāriyāt. Dalam hal ini bisa digambarkan sebagai berikut:

\begin{tabular}{|l|l|l|l|lr|}
\hline Laki-laki & Tamu & Malaikat & $\begin{array}{l}\text { Tidak mau } \\
\text { makan }\end{array}$ & $\begin{array}{l}\text { Memberi kabar } \\
\text { gembira }\end{array}$ & $\begin{array}{r}\text { akan } \\
\hline\end{array}$ \\
\hline
\end{tabular}




\begin{tabular}{|l|l|l|l|l|}
\hline & & & & dikaruniai Ishāq \\
\hline Ibrahim & Tuan rumah & Nabi & $\begin{array}{l}\text { Memberi } \\
\text { hidangan } \\
\text { daging sapi }\end{array}$ & $\begin{array}{l}\text { Terkejut } \\
\text { Merasa sudah } \\
\text { terlalu tua }\end{array}$ \\
\hline
\end{tabular}

\section{Ibrahim dan Ujian Berkurban}

Salah satu kisah Ibrahim yang dianggap sangat menguji kesabarannya adalah kisah tentang penyembelihan Ibrahim terhadap puteranya. Ibrahim yang setelah sekian lama tidak memiliki anak yang kemudian dianugerahi seorang putera dari istri keduanya, Siti Hajar, dia kemudian bermimpi diperintahkan oleh Allah untuk menyembelihnya. Ismāîl yang juga merupakan anak yang saleh, dengan kesabarannya juga bersedia untuk disembelih oleh Ibrahim. Namun, hingga titik terakhir akan disembelihnya Ismā‘̂îl, Ibrahim mendapatkan petunjuk dari Allah untuk mengganti kurbannya dengan kambing besar. Kisah ini terekam dalam surah al-Ṣāffāt.

Kisah tentang penyembelihan putra Ibrahim ini juga dijelaskan dalam Bibel, yang menyatakan bahwa Ishāq adalah putera yang disembelih. Sedangkan mayoritas ulama Islam meyakini bahwa yang disembelih oleh Ibrahim adalah Ismāîi.$^{19}$ Namun demikian, Alquran menjelaskan bahwa baik Ismā̄îl maupun Ishạāq, keduanya merupakan anak yang saleh dan keduanya sama-sama menjadi Nabi. Jika nabi Ismāîl dilahirkan dari rahim Siti Hajar, maka Ishạā dilahirkan dari Sarah. Dalam Alquran, keduanya digambarkan sebagai orang yang sabar, alim, dan saleh.

\section{Pribadi Nabi Ibrahim}

Alquran juga mengisahkan tentang sosok pribadi Nabi Ibrahim dalam surah al-Naḥl, Ṣād, al-Mumtahanah. Sosok Nabi Ibrahim yang masuk golongan ulul azmi ini menjadi sosok teladan, tidak hanya bagi para nabi-nabi setelahnya, tetapi juga seluruh umat manusia. Cobaan hidup yang cukup berat pernah dialaminya, tetapi semua itu justru menjadikan dirinya sebagai sosok yang sabar dan tawakal. Sehinggga, Ibrahim tidak hanya menjadi orang yang diberikan kebaikan di dunia

\footnotetext{
${ }^{19}$ Perlu diketahui, bahwa dalam Islam pun terdapat riwayat yang menyatakan bahwa Ishāa adalah putra yang disembelih. Riwayat semacam itu dapat dijumpai dalam karya sejarawan sekaligus mufassir, Ibn Jarīr al-Ṭabarī. Selengkapnya lihat Ibn Jarīr al-Ṭabarī, Jāmi‘ al-Bayān fì Ta'mūl al-Qur'ān, vol 21 (Beirut: Mu'assasat al-Risālah, 2000), 74 .
} 
tetapi juga termasuk golongan orang-orang saleh di akhirat. Sosok Nabi Ibrahim di dalam Alquran digambarkan sebagai: 1) Nabi utusan Allah; 2) imam teladan; 3) orang yang bersyukur atas nikmat Allah; 4) orang yang tidak menyekutukan Allah; 5) orang yang diberi petunjuk; 6) orang yang diberi kebaikan di dunia; 7) termasuk golongan orang saleh di akhirat.

\section{Agama Ibrahim}

Alquran juga menyebutkan tentang agama yang diajarkan oleh Ibrahim kepada kaumnya. Agama ini kemudian juga menjadi agama yang diikuti oleh para nabi sesudahnya, termasuk Nabi Muhammad. Agama yang lurus, atau dalam istilah Alquran disebut dengan ḥanif, merupakan ajaran agama yang berporos pada penyerahan diri hanya kepada Allah. Ibrahim dengan tegas menyatakan bahwa agama yang dianutnya bukanlah agama Yahudi dan bukan pula agama Nasrani, namun merupakan ajaran dari agama yang lurus (ḅanif)

Terkait dengan agama (millab) Ibrahim ini, ada orang yang membenci agama Ibrahim dan ada pula yang mengikutinya. Sebagaimana dijelaskan dalam Alquran, mereka yang membencinya digambarkan sebagai orang yang mencelakakan diri dan mencampuradukan keimanan dan kezaliman yang mengakibatkan mereka tidak mendapatkan keamanan. Selain itu, Alquran juga menyebutkan bahwa orang yang lebih baik agamanya adalah orang yang ikhlas, yang mau menyerahkan diri kepada Allah, mengerjakan kebaikan dan mengikuti agama Ibrahim yang lurus.

\section{Struktur Kisah Ibrahim Dalam Alquran}

Dari transformasi relasi paradigmatic, sebagaimana digambarkan diatas, struktur diakronik dari tahapan sejarah kehidupan yang dilalui oleh nabi Ibrahim secara lengkap digambarkan oleh Alquran, mulai dari masa kecil, masa muda, dewasa hingga masa tua yang bisa digambarkan sebagai berikut: 


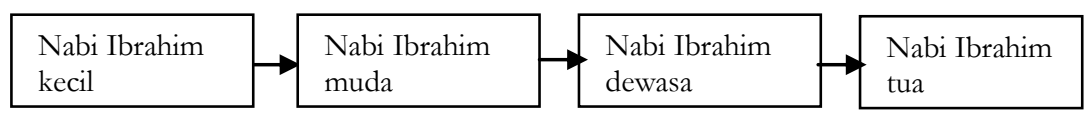

\begin{tabular}{|c|c|}
\hline \begin{tabular}{l}
\multicolumn{1}{c}{ Masa kecil } \\
-Merasakan kegalauan teologis \\
-Merenung \\
-Suka memunculkan pertanyaan- \\
pertanyaan kritis
\end{tabular} & $\begin{array}{l}\quad \text { Masa muda } \\
\text {-Keyakinan yang semakin kuat } \\
\text {-Mampu menunjukkan kesesatan } \\
\text { ayahnya }\end{array}$ \\
\hline $\begin{array}{l}\text { Ibrahim Tua } \\
\text { - Tetap melakukan dakwah } \\
\text { - Membangun Baitullah } \\
\text {-Menyembelih Ismācīl } \\
\text {-Mendapat anugerah putera Ishāāq }\end{array}$ & $\begin{array}{l}\quad \text { Masa Dewasa } \\
\text {-Terus dakwah dan berani } \\
\text { mengambil resiko } \\
\text {-Menghancurkan berhala } \\
\text {-Menghadapi Raja Namrud } \\
\text {-Membuktikan mukjizat } \\
\text { menghidupkan burung }\end{array}$ \\
\hline
\end{tabular}

Dalam menjalani kehidupannya, Nabi Ibrahim tidak pernah lepas dari segala cobaan. Cobaan hidup yang berat dan ketabahan yang ditunjukkan oleh Ibrahim membuatnya termasuk golongan orangorang yang sabar. Cobaan tersebut diterimanya pada setiap tahap dari kehidupannya, cobaan yang tidak hanya datang dari kaum yang menentangnya, tetapi juga cobaan yang datang dari Allah. Cobaan tersebut bisa digambarkan sebagai berikut:

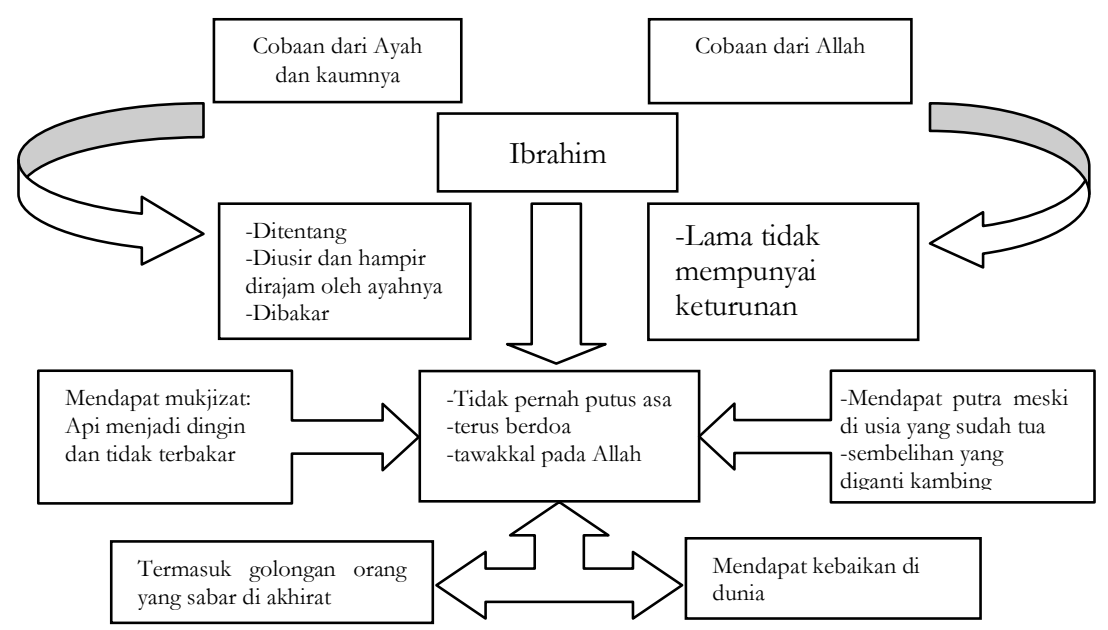


Demikianlah fase-fase kehidupan Nabi Ibrahim, berikut cobaancobaan yang yang dilaluinya dalam setiap tahapan. Cobaan yang begitu berat diluar cobaan yang dihadapi manusia biasa. Dia harus berhadapan dengan ayahnya sendiri, seorang yang sangat dicintainya, karena perbedaan pandangan dan kepercayaan. Karenanya, meski sang ayah hendak merajam dan mengusirnya, Ibrahim tetap mendoakan ayahnya, memohon ampun dan beristigfar untuk sang ayah. Karena dia tidak menginginkan ayahnya jatuh pada kemusyrikan yang akan membawanya pada jalan kesesatan. Kemudian pada masa mudanya, Ibrahim harus menghadapi kaumnya yang semakin kuat menentangnya, menghadapi seorang raja yang kejam dan zalim. Dia juga menghadapi cobaan yang luar biasa, yakni usaha pembunuhan dan pembakaran. Setelah selamat dari pembakaran, Ibrahim akhirnya memutuskan untuk meninggalkan tanah kelahirannya dan berhijrah ke Palestina bersama istrinya, Sarah, dan sepupunya, nabi Luth. Cobaan yang diterimanya juga belum berhenti. Karena Ibrahim yang saat itu telah lama menikah dengan Sarah belum juga dikaruniai keturunan. Dia tidak putus asa untuk memohon kepada Allah. Kemudian atas izin Sarah, Ibrahim akhirnya menikah dengan Hajar dan dikaruniai seorang putera, Ismāîil. Kelahiran Ismā'îl yang begitu dinanti membuat kehidupan Ibrahim menjadi berwarna. Tetapi kebahagiaan tersebut juga tidak lepas dari cobaan. Nabi Ibrahim diperintahkan oleh Allah melalui mimpinya untuk mengorbankan puteranya Ismā'îl. Atas persetujuan Ismā'îl, Ibrahim melakukan penyembelihan terhadap putera yang teramat disayanginya. Namun setelah itu, Allah menggantikan penyembelihan Ismāîl dengan kambing yang besar.

Kisah Nabi Ibrahim sebagaimana yang tertulis di atas sebenarnya merupakan penjelasan dari isu paling krusial yang diangkat dalam Alquran, yakni masalah tauhid atau akidah. Hal ini karena ajaran Islam yang merupakan tatanan dan norma bagi orang muslim semuanya berakar dari persoalan tauhid. Tauhid atau paham monoteisme adalah keyakinan akan satu Tuhan, satu Pencipta, dan satu pemelihara alam semesta, yang sebagai konsekuensinya, maka lahir tauhid 'amali dan tauhid ibadah. Tauhid 'amali adalah meninggalkan ibadah karena selain Allah dan bukan sekedar meyakini ke-Esaannya. Sedangkan tauhid ibadah mencegah dari beribadah selain Allah. Dari sini kemudian, maksud Alquran lewat gambaran kisah nabi Ibrahim adalah agar mereka paham benar hakikat Tuhan. Ketauhidan merupakan hakikat dari ketundukan seorang manusia kepada kekuatan yang maha agung 
dan sakral, yang dalam Alquran disebutkan hanyalah milik Tuhan yang satu, yaitu Allah. ${ }^{20}$

Pengalaman teologis Nabi Ibrahim bukan semata-mata dari pengetahuan atau wahyu yang telah diberikan oleh Allah, tetapi pengalaman tersebut diawali dari nalar kritisnya sebagaimana yang digambarkan dalam surah al-An'ām dan kemudian diikuti dengan pengetahun dan wahyu dari Allah. Kegelisahan Ibrahim terhadap apa yang disembah oleh ayah dan kaumnya melalui nalar kritis sebelum adanya petunjuk dari Allah merupakan fitrah yang dimiliki oleh semua manusia. Sebagaimana disebutkan dalam QS. al-Rūm [30]: 30 yang artinya: "Maka hadapkanlah wajahmu dengan lurus kepada agama Allah; (tetaplah atas) fitrah Allah yang telah menciptakan manusia menurut fitrah itu. tidak ada perubahan pada fitrah Allah. (Itulah) agama yang lurus; tetapi kebanyakan manusia tidak mengetahui". ${ }^{21}$

Ayat tersebut menjelaskan bahwa keberagamaan menurut versi Alquran adalah tabiat umum kemanusiaan. Jadi agama adalah fitrah Allah yang dengannya manusia diciptakan. Keberagamaan adalah satu universalitas abadi yang dimiliki oleh semua orang, baik mereka yang sudah mengenal peradaban maupun yang masih terbelakang. Fitrah adalah bukti adanya kekuatan agung nan sakral bagi semua makhluk hidup. Namun sayang fitrah ini justru oleh mereka (sebagian manusia) diselewengkan untuk selain Allah. Mereka menganggap kekuatan agung nan sakral ini adalah milik berhala-berhala mereka. ${ }^{22}$

Dalam konteks kisah Ibrahim, dia mengetahui kesesatan ayah dan kaumnya bukan karena dia sudah menerima wahyu, tetapi karena fitrahnya. Fitrah Ibrahim yang suci itu diperkuat dengan argumen akalnya yang mendasarkan pengamatannya pada fenomena alam. Sementara ayah dan kaumnya tersesat karena mereka tidak menghidupkan fitrahnya dan lebih mengikuti kepercayaan dan prilaku nenek moyangnya. Disini ayah dan kaum Ibrahim bukan tidak percaya kepada Tuhan (Zat yang maha Tinggi), tetapi pemahaman mereka mengenai sesuatu yang maha Tinggi itulah yang dianggap sesat. Hal ini terlihat dari cara penyembahan terhadap-Nya yang memakai mediasi berupa patung atau berhala. Tuhan yang dikonsepsikan mereka juga tidak tunggal, tetapi banyak, sehingga mereka jatuh pada

\footnotetext{
20 Muhammad Aḥmad Khalafullāh, Al-Quran bukan Kitab Sejarab: Seni, Sastra dan Moralitas dalam Kisah-kisah Alquran, terj. Zuhairi Misrawi dan Aris Maftuhin (Jakarta: Paramadina, 2002), 87-88.

21 Departemen Agama, Al-Hikmah, 407.

${ }^{22}$ Khalafullāh, Al-Quran bukan Kitab, 88.
} 
kemusyrikan. Praktek semacam inilah yang kemudian dianggap kafir. Terkait dengan hal ini, bisa digambarkan dalam struktur di bawah ini:

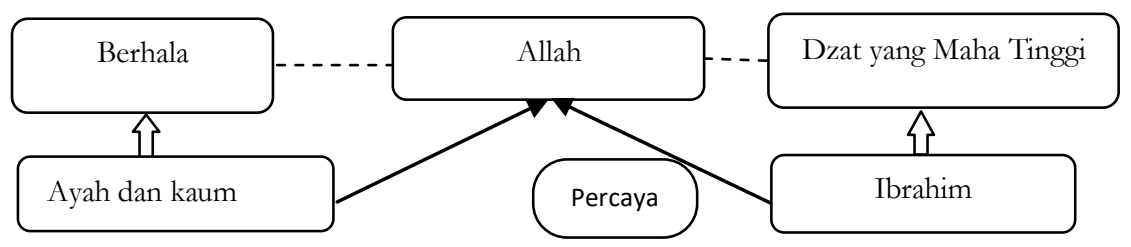

Kegelisahan teologis nabi Ibrahim berlanjut dengan diberikannya petunjuk dari Allah. Hal ini semakin mempertegas keyakinan Ibrahim akan ke-Esa-an Allah. Ketika Ibrahim menemukan pemahaman ketuhanannya, maka Ibrahim kemudian mendapat predikat hanif. ${ }^{23}$ Sehingga agama Ibrahim bukan hanya agama fitrah tetapi juga agama ḩanif. Kata ḩanif menurut Hazrat Mirza Nashir Ahmad dalam The Holy Qur'an, sebagaimana yang dikutip oleh Dawam Raharjo, merujuk kepada beberapa sumber yakni: (a) orang yang meninggalkan dan menjauhi kesalahan dan mengarahkan dirinya kepada petunjuk, (b) orang yang secara terus menerus mengikuti kepercayaan yang benar tanpa keinginan untuk berpaling padanya, (c) seseorang yang cenderung menata perilakunya secara sempurna menurut Islam dan terus menerus mempertahankannya secara teguh, (d) seseorang yang mengikuti agama Ibrahim, (e) orang yang percaya kepada seluruh nabi-nabi. ${ }^{24}$ Dengan demikian, hanif merupakan ungkapan yang bermakna mengembalikan ke-Esa-an Allah secara sempurna. Hanif adalah agama yang jauh dari kemusyrikan dan mengajak kepada ketauhidan, baik ulühìyah maupun rubübìah. Hanif bukan semata-mata tidak musyrik, tetapi juga secara konsisten menjalankan perintah agama, bukan sekedar kepercayaan yang benar, tetapi juga menjalankan syariat yang ada di dalamnya. Karena itulah mengapa ayah dan kaum Ibrahim dikatakan tidak ḥanif. Karena meskipun mereka percaya kepada Tuhan yang Maha tinggi, tetapi hal itu tidak terimplementasi hingga pada cara beribadah mereka kepada-Nya.

\footnotetext{
23 Hanif berasal dari kata ḩanafa yang berarti condong atau cenderung ke tengah, seperti condongnya dua tungkai kaki ke tengah. Hanafa juga berarti cenderung menjauh dari dua kutub ekstrim yang berlebihan dan mengarah ke tengah dan kepada yang benar. Dari pengertian ini, maka maksud dari kata ḥanafa adalah condong kepada istiqāmah dan keadilan atau kebenaran. Lihat, Al-Rāghib alAṣfahānī, Al-Mufradāt fì Gharīb al-Qur'ān (Beirut: Dār al-Qalam, 1992), 133.

${ }^{24}$ Raharjo, Ensiklopedi Alquran, 62.
} 
Predikat ḩanif itu tidak hanya karena Ibrahim adalah seorang monoteis tetapi juga karena Ibrahim adalah seorang yang pasrah kepada Tuhannya (Islam). Sebaliknya, ayah dan kaum Ibrahim sebagai seorang yang tidak hanif kemudian disebut sebagai penganut politeis (musyrik).

\section{Relasi antara Bulan, Bintang, Matahari dengan Patung dan Namrud}

Dalam kisah Nabi Ibrahim yang tersebar di banyak ayat dan surah di dalam Alquran, terlihat beberapa relasi yang terdapat di dalamnya. Salah satu diantaranya adalah relasi antara bulan, bintang dan matahari dengan patung dan raja Namrud. Bulan, bintang dan matahari, sebagaimana yang tertulis di dalam QS. al-An‘ām [6]: 76-79, merupakan refleksi awal yang dilakukan oleh nabi Ibrahim dikala masih kecil. Dengan menggunakan kekuatan akalnya (fitrah), dia bersikap kritis terhadap patung-patung yang dipahat oleh ayahnya yang kemudian disembahnya. Bagi Ibrahim, Tuhan yang Maha Kuasa atas segala sesuatu bukanlah Tuhan yang bisa diciptakan, apalagi oleh tangan manusia. Ketika bintang muncul di malam hari, Ibrahim sempat menganggap apakah ini yang dinamakan Tuhan, akan tetapi ketika bintang itu tenggelam bersama hilangnya malam, dia sadar bahwa itu bukanlah Tuhan, karena tidak mungkin Tuhan akan tenggelam. Begitu juga ketika bulan muncul, Ibrahim sempat bertanya pada dirinya sendiri apakah itu Tuhan. Tetapi ketika bulan tenggelam diapun tidak mempercayainya. Sampai pada pagi harinya ketika matahari terbit, dia menganggap matahari itulah Tuhan, tetapi begitu matahari tenggelam, dia menyadari bahwa itu bukan Tuhan. Baik bintang, bulan maupun matahari, ketiganya sama-sama pernah disangka Tuhan oleh Ibrahim, meski akhirnya dia menyadari bahwa Tuhan tidak bisa diserupakan dengan sesuatu apapun.

Sementara itu, ayah Ibrahim, Azar, dan kaumnya merupakan para penyembah patung. Menyembah patung sudah menjadi adat kebiasaan turun temurun dalam masyarakat di mana Ibrahim lahir dan dibesarkan. Para penyembah patung percaya bahwa malaikat, jin atau sifat sembahan adalah sesuatu yang imaterial. Karena itu, mereka melambangkannya dalam bentuk material. Dengan demikian, pada hakikatnya mereka tidak menyembah berhala tetapi apa yang dilambangkan oleh patung itu. Ibrahim mempertanyakan apakah patung-patung tersebut bisa mendengar keluhan dan permohonan 
mereka, apakah patung-patung tersebut bisa memberi manfaat kepada mereka jika mereka tekun beribadah, dan memberi madarat jika mereka tidak tekun beribadah. Pertanyaan tersebut mengisyaratkan bahwa Ibrahim meminta agar mereka merenung, mempergunakan akal dan fitrah mereka, dengan harapan mereka bisa sadar bahwa berhala-berhala yang mereka hadapi adalah benda mati yang tidak sedikitpun memiliki kemampuan. Tetapi mereka menjawab setelah menyadari apa yang dipertanyakan oleh Ibrahim bahwa bukan karena itu, mereka menyembah patung tetapi sebenarnya mereka hanya mendapati nenek moyang mereka senantiasa melakukan perbuatan tersebut, sehingga mereka juga melakukannya. ${ }^{25}$

Ayat-ayat Alquran menceritakan tentang bagaimana kaum Nabi Ibrahim itu menyembah patung yang tidak bisa memberi manfaat dan tidak bisa berbuat apa-apa, bahkan tidak bisa mendengar dan berbicara. Karenanya patung-patung tersebut tidaklah layak untuk dipertuhankan. Adapun Namrud, dia adalah seorang raja yang dikenal dengan raja yang dzalim. Raja Namrud (hidup sekitar tahun 2275 SM1943 SM) disebut juga dengan Namrud b. Kan'an. Dia adalah salah satu seorang raja yang memerintah Mesopotamia purba (kini dikenali negara Iraq). Dia dijuluki dengan "a mighty hunter" yang berarti "pemburu yang hebat". Pada zamannya, Namrud merupakan seorang raja yang cerdas dan dianugerahi dengan daya intelek yang tinggi dan menjadi pakar dalam pelbagai bidang seperti matematika dan ilmu falak. Namrud telah menemui system desimal yang membagi bulatan menjadi 360 derajad, satu derajad dibagi menjadi 60 menit dan 1 menit dibagi menjadi 60 detik. Selain itu, dia juga menetapkan bahwa satu hari terbagi menjadi 24 jam dan setiap jam dibagi 60 menit dan 1 menit kepada 60 detik. Menurutnya hari dimulai pada waktu tengah malam dan bukannya pada waktu matahari terbenam seperti yang dipercayai oleh kaum sebelumnya.

Karena kecerdasannya, Namrud menjadi seorang ateis yang tidak hanya mempercayai akan adanya Tuhan yang Maha Kuasa dan Pencipta alam semesta. Dia bahkan menganggap dirinya sendiri adalah tuhan. Dia merasa tuhan karena dia bisa mematikan seseorang. Hal ini karena memang dia adalah seorang Raja yang dikenal kejam. Namun demikian, Ibrahim bisa menunjukkan bahwa dia hanyalah seorang raja dan bukan tuhan. Karena yang disebut Tuhan adalah jika dia mampu menciptakan langit dan bumi dan bisa menghidupkan dan mematikan

${ }^{25}$ Shihab, Tafsir al-Mishbah, vol. 3, 251-252. 
semua mahluk di dunia ini. Meski Ibrahim telah meyakinkan Namrud dengan bukti-bukti kekuasaan Allah. Tetapi Namrud tetap tidak mau merubah keyakinannya dan tetap menganggap dirinya sebagai tuhan serta memerintahkan kaumnya untuk menyembahnya.

Dari sini, terlihat adanya relasi analogis antara bulan, bintang dan matahari dengan patung dan Namrud. Hubungan di antara hal tersebut terlihat dari ketiganya yang sama-sama pernah dianggap tuhan dan sama-sama tidak bisa membuktikan atau tidak bisa menunjukkan sifat-sifat yang seharusnya dimiliki oleh Tuhan. Bulanbintang-matahari karena sifatnya yang muncul dan tenggelam telah membuktikan bahwa memang bukan tuhan. Sedangkan patung/berhala karena memang tidak bisa berbicara dan berbuat apaapa, apalagi patung tersebut juga buatan manusia, tentu saja tidak pantas untuk disembah. Sedangkan raja Namrud, meski dia seorang raja dan punya kekuasaan, dia tidak bisa membuktikan bahwa dirinya adalah tuhan.

\section{Relasi antara Burung, Api, dan Kambing}

Dalam kisah Ibrahim diatas, diceritakan bahwa Ibrahim beberapa kali mengalami peristiwa yang luar biasa dalam hidupnya. Peristiwa tersebut dapat ditemukan relasi paradigmatis bahwa ketiganya berada dalam bingkai pengorbanan, dakwah, dan upaya untuk menyeru keimanan kepada Allah. Pertama, pada saat Nabi Ibrahim dituntut membuktikan kekuasaan Allah untuk bisa menghidupkan orang mati, maka Allah memerintahkan Ibrahim untuk menyembelih empat ekor burung dan mencacahnya menjadi beberapa bagian. Potonganpotongan burung tersebut kemudian diletakkan di empat bukit yang berbeda. Setelah itu, Ibrahim memanggil burung-burung tersebut dan seketika burung-burung yang telah terpotong-potong dan dipisahkan bangkai tubuhnya bisa menyatu dan terbang kembali. Peristiwa ini mengingatkan bahwa sangat mudah bagi Allah untuk mematikan dan juga menghidupkan mahluk yang telah mati. Karenanya, hari akhir atau hari kiamat di mana semua manusia yang telah mati akan dihidupkan kembali untuk mempertanggungjawabkan perbuatannya merupakan hal yang mudah bagi Allah dan bukan hal mustahil.

Kedua, peristiwa pembakaran yang dilakukan oleh kaumnya. Peristiwa ini juga terjadi karena Ibrahim telah menghancurkan patungpatung sesembahan mereka. Sebelum pembakaran ini terjadi, Ibrahim tidak hanya menghancurkan patung-patung berhala, tetapi juga 
menyisakan patung yang paling besar. Upaya ini dilakukan oleh Ibrahim agar mereka bisa menengok diri mereka sendiri, yakni berpikir, dan akhirnya sadar bahwa mereka menyembah sesuatu yang tidak berakal. Namun ternyata yang terjadi adalah sebaliknya, mereka tidak lagi menggunakan akal sehat mereka. Kaum Nabi Ibrahim merasa terpojok dan marah. Sebagaimana kebiasaan orang kuat yang merasa terpojok, mereka sepakat untuk menghabisi Ibrahim, yakni dengan cara membakarnya. Dengan pembakaran tersebut, mereka hendak membuat makar terhadap Ibrahim, yakni membunuh dan juga menghabisi ajaran-ajarannya. Kemudian Allah memerintahkan api yang membakar Ibrahim menjadi dingin dan menyelamatkannya. Sesuatu hal yang tidak pernah terjadi sebelumnya dan merupakan hal yang luar biasa karena diluar hukum alam yang dikenal selama ini. ${ }^{26}$

Ketiga, peristiwa penyembelihan yang sekaligus merupakan ujian berat bagi Ibrahim. Diawali dengan mimpi nabi Ibrahim pada saat beliau sedang berada di Mekkah. Dia mendengar seruan Allah yang memerintahkannya agar dia menyembelih anaknya. Nabi Ibrahim bangun dari tidurnya dalam keadaan terkejut dengan mimpinya yang aneh itu. Nabi Ibrahim mengetahui bahwa perintah tersebut merupakan ujian yang harus dia jalani. Amat berat bagi Ibrahim untuk memberitahu isi wahyu itu kepada putranya yang pada saat itu menginjak dewasa. Nabi Ibrahim sangat senang karena Ismāôil sudah besar. Nabi Ibrahim memberitahu perintah Allah tersebut kepada Ismāîl. Sebagai seorang anak yang salih dan penurut, dia menjawab: "Wahai ayahku, kerjakanlah apa yang Allah perintahkan kepadamu. Insya Allah ayah akan mendapati aku sebagai orang yang sabar dalam menjalankan perintah Allah.

\section{Kesimpulan}

Alquran menampilkan kisah Ibrahim pada sisi perjalanan dakwahnya yang dapat dijadikan sebagai barometer untuk menjauhkan jiwa dari perbuatan syirik. Dalam kisah-kisah Alquran, Nabi Ibrahim memang ditampilkan sebagai tokoh yang paling getol memberantas kemusyrikan. Sehingga tidak mengherankan jika kisah Ibrahim tentang usaha pemberantasan penyembahan terhadap berhala ini diulang dalam beberapa surah. Dalam paradigma strukturalisme, pengulangan-pengulangan tersebut bisa menggambarkan adanya relasi-relasi paradigmatik yang bisa mengungkap makna. Melalui

${ }^{26}$ Ibid., 83-84. 
analisa strukturalisme hermeneutika, setidaknya gambaran tentang kisah Ibrahim di dalam Alquran tersebut menjadi semakin jelas. Melalui transformasi relasi paradigmatic, kisah Ibrahim semakin terlihat alur historisnya (diakronik). Relasi yang lain juga terlihat ketika pengalaman Ibrahim ini dikaitkan dengan dakwah nabi Muhammad, dimana terdapat relasi antara Ibrahim dan Muhammad sebagai sesama utusan Allah yang mengajarkan umatnya tentang keesaan Allah dengan melakukan dialog, meski pada akhirnya umatnya tetap tidak mau menerima kebenaran yang telah disampaikan.

\section{Daftar Pustaka}

Aṣfahānī (al), al-Rāghib. Al-Mufradāt fì Gharìb al-Qứàn. Beirut: Dār alQalam, 1992

Abdul Ghafur, Waryono. Millah Ibrabim dalam Tafsir Al-Mizan fi Tafsir Alquran karya Muhammad Husein Ath-Thaba'thaba'i. Yogyakarta: Bidang Akademik UIN Sunan Kalijaga, 2008

Ahimsa-Putra, Heddy Shri. Strukturalisme Levi-Strauss; Mitos dan Karya Sastra. Yogyakarta: Kepel Press, 2012 .

Khalafullāh, Muhạmmad Aḥmad. Al-Quran bukan Kitab Sejarah: Seni, Sastra dan Moralitas dalam Kisah-kisah Alquran. terj. Zuhairi Misrawi dan Anis Maftuhin. Jakarta: Paramadina, 2002.

Arkoun, Mohammad. Rethinking Islam. terj. Yudian W. Asmin dan Lathiful Khuluq. Yogyakarta: LPMI dan Pustaka Pelajar, 1996.

Hanafi, A. Segi-segi Kesusastraan Pada Kisah-kisah Alquran. Jakarta: Pustaka alhusna, 1983.

Jābirī (al), 'Ābid. Madkhāl ilā al-Qur'ān al-Karim: al-Juz al Awwal fì al Ta'ríf bi al-Qur'ān. Beirut: Markaz Dirāsat al-Wiḥdah al'Arabìyah, 2006.

Kathīr (ibn), Abū al-Fidā' Ismā̄îl. Tafsìr al-Qur'ān al-'Adhim. Kairo: Dār Tayyibah, 1999.

Qalyubi, Shihabbuddin. Stilistika Alquran: Makna di Balik Kisah Ibrahim. Yogyakarta: LKiS, 2008

Rahman, Fazlur. Tema-tema Pokok Al-Qur'an. terj. Ervan Nurtawab dan Ahmad Baiquni. Bandung: Mizan Pustaka, 2017.

Raharjo, Dawan. Ensiklopedi Alquran: Tafsir Sosial Berdasarkan Konsepkonsep Kunci. Paramadina: Jakarta, 2002

Shihab, M. Quraish, Mukjizat Alquran; Ditinjau dari Aspek. Kebahasaan, Isyarat Ilmiah, dan Pemberitaan Gaib. Bandung: Mizan, 2007. 
- Tafsir al-Mishbab; Kesan, Pesan dan Keserasian al-Qur'an. Jakarta: Lentera Hati, 2002.

Suyūṭī (al), Jalāl al-Dīn. Al-Itqān fì 'Ulūm al-Qư'àn. Kairo: Hai'at alMișrīyah al-'Āmmāh li al-Kitāb, 1974.

Syamsudin, Sahiron. Hermeneutika dan Pengembangan Ulumul Qur'an, Yogyakarta: Pesantren Nawesea Press, 2009.

Ṭabarī (al), Ibn Jarīr. Jāmi al-Bayān fì Ta'wūl al-Qur'àn. Beirut: Mu'assasat al-Risālah, 2000. 